\title{
Local action of trophoblast interferons in suppression of the development of oxytocin and oestradiol receptors in ovine endometrium
}

\author{
G. E. Lamming ${ }^{1}$, D. C. Wathes ${ }^{2}$, A. P. F. Flint ${ }^{1}$, J. H. Payne ${ }^{1}$, \\ K. R. Stevenson ${ }^{2}$ and J. L. Vallet ${ }^{3}$ \\ ${ }^{\mathrm{I}}$ Department of Animal Physiology and Environmental Science, University of Nottingham, \\ Sutton Bonington Campus, Sutton Bonington, Loughborough, Leics, LE12 5RD, UK; ${ }^{2}$ Department of \\ Farm Animal and Equine Medicine and Surgery, Royal Veterinary College, Hawkshead Road, Potters Bar, \\ Herts, EN6 1NB UK; and ${ }^{3}$ US Meat Animal Research Centre, Clay Centre, Nebraska, USA.
}

Luteolysis in sheep is associated with uterine secretion of pulses of prostaglandin $\mathrm{F}_{2 u}\left(\mathrm{PGF}_{2 u}\right)$ due to the action of luteal oxytocin on endometrial oxytocin receptors. For pregnancy to become established inhibition of oxytocin receptors is important as an antiluteolytic mechanism. The maternal recognition of pregnancy in cattle and sheep involves production, by the trophoblast, of a type 1 interferon (IFN- $\tau$ ) that suppresses uterine development of oxytocin receptors and the generation of luteolytic episodes of $\mathrm{PGF}_{2 \alpha}$. The action of IFN- $\tau$ in surgically prepared unilaterally pregnant ewes was investigated. Finn-Dorset ewes were anaesthetized on day 6 or 7 of the oestrous cycle and one uterine horn was surgically isolated at the uterine bifurcation from the body of the uterus. Ewes were mated at the subsequent oestrus either by a fertile or by a vasectomized ram and killed on day 13 or 16 after mating. On day 16, in the non-pregnant ewes, there was no measurable uterine IFN- $\tau$ but there were high concentrations of oxytocin receptors in both horns. In the pregnant ewes, on day 16 after mating, the oxytocin receptor concentration was $45 \pm 11 \mathrm{fmol} \mathrm{mg}^{-1}$ protein in the pregnant horn and $585 \pm 131 \mathrm{fmol} \mathrm{mg}^{-1}$ in the non-pregnant horn. Antiviral activity was $5.8 \times 10^{7} \pm 5.2 \times 10^{7} \mathrm{U} \mathrm{ml}^{-1}$ in the pregnant horn and $2.9 \times 10^{3} \pm 1.2 \times 10^{3} \mathrm{U}$ $\mathrm{ml}^{-1}$ in the non-pregnant horn. Thus, 16 days after mating, the pregnant horn exhibited high antiviral activity but oxytocin receptors were suppressed, while in the same endocrine environment (characteristic of pregnancy) there were low IFN- $\tau$ and high oxytocin receptor concentrations in the isolated horn equivalent to those expected at the onset of luteolysis. In situ hybridization to ovine mRNA encoding the oxytocin receptor and autoradiographic studies using the ${ }^{125}$ I-labelled oxytocin antagonist $\mathrm{d}\left(\mathrm{CH}_{2}\right)_{5}\left[\mathrm{Tyr}(\mathrm{Me})^{2}, \mathrm{Thr}^{4}\right.$, Tyr- $\left.\mathrm{NH}_{2}{ }^{9}\right]$ vasotocin both showed that the large amount of oxytocin receptor message and binding sites in the endometrium of the isolated horn were localized in the luminal epithelium. Immunocytochemical studies showed that there was a suppression of oestradiol receptors in the pregnant horn but high concentrations equivalent to those at oestrus were present in the isolated horn. The content of progesterone receptors was low in the stromal tissue only in both horns, a pattern of localization similar to that seen in the late luteal phase and in early pregnancy. These results are consistent with a local action of IFN- $\tau$ on endometrial oxytocin receptors and endometrial oestrogen receptors; they raise the possibility that reduced oestrogen receptor function mediates the inhibitory effect of IFN- $\tau$ on oxytocin receptor expression, but the exact relationship between the suppression of oestradiol and oxytocin receptors in relation to the antiluteolytic action of IFN- $\tau$ requires further study.

\section{Introduction}

Luteolysis in sheep is caused by the episodic release of prostaglandin $\mathrm{F}_{2 u}\left(\mathrm{PGF}_{2 \alpha}\right)$ from the uterus (McCracken ef al.,

Received 7 April 1995.
1972). The episodic nature of $\mathrm{PGF}_{2 \alpha}$ secretion is the result of a positive feedback loop in which oxytocin, secreted by the corpus luteum, acts at uterine oxytocin receptors to stimulate $\mathrm{PGF}_{2 u}$ (for review see Flint et al, 1992); this in turn acts on the corpus luteum to release further oxytocin (Flint and Sheldrick, 1983). The time at which luteal regression occurs is 
influenced by the time at which oxytocin receptors are generated in the uterus (Sheldrick and Flint, 1985; for reviews see Wathes et al., 1993; Flint et al., 1994; Wathes and Lamming, 1995).

The maternal recognition of pregnancy in sheep involves the secretion by the developing blastocyst of trophoblastic interferon (IFN- $\tau$ ) between days 13 and 21 after mating (Godkin et al., 1982). IFN- $\tau$ is secreted into the uterine lumen and inhibits the increase in the uterine concentration of oxytocin receptors (Vallet and Lamming, 1991) that normally occurs during the period after the inhibitory effect of circulating progesterone on oxytocin receptor concentration (Vallet et al., 1990). It is thought that this effect is exerted locally on the uterus, although it is not known whether there are systemic effects exerted indirectly, for example, via subtle changes in the systemic hormonal environment. There is some evidence against a systemic effect of IFN- $\tau$ on the inhibition of luteolysis since it has been shown that in unilaterally pregnant sheep the contralateral corpus luteum regresses (Moor and Rowson, 1966). What is not clear is the association of oxytocin receptors with the inhibition of luteolysis by IFN- $\tau$ and how much of the decrease in oxytocin receptors during pregnancy is due to a local effect of the conceptus and how much is due to the maintenance of progesterone concentrations during pregnancy.

In addition to the effect of progesterone, circulating oestrogen concentrations also control the expression of oxytocin receptors (Beard and Lamming, 1994). Neither rat nor human genes encoding oxytocin receptors contain classical oestrogen responsive element (ERE) consensus sequences in the $5^{\prime}$ flanking region, although widely spaced half-palindromic ERE motifs are present, which could potentially mediate the action of oestradiol directly (Inoue et al., 1994; Rozen et al., 1995). Therefore, endometrial concentrations of both oestrogen and progesterone receptors may be involved in responses of the oxytocin receptor to pregnancy, and these receptors were also studied.

The aim of this study was to investigate the effect of a conceptus on the content of oxytocin receptors in the uterus in ewes with surgically prepared uteri which allowed the pregnancy to be established in one uterine horn, whilst isolating the non-pregnant uterine horn.

\section{Materials and Methods}

\section{Animal management}

Experiment 1. Between day 6 and day 9 (oestrus = day 0 ), cyclic Finn-Dorset ewes were anaesthetized with $2.5 \%$ thiopentone (May and Baker Ltd, Dagenham) administered i.v. $\left(0.6 \mathrm{ml} \mathrm{kg}^{-1}\right.$ body mass) and anaesthesia was maintained with halothane in oxygen and nitrous oxide at a ratio of 2:1. The uterus was exposed via a midline laparotomy incision. One uterine horn (that ipsilateral to an active corpus luteum) was sectioned, the endometrium cauterized, and the myometrium of the two ends sutured, resulting in the uterine body and one uterine horn being totally isolated from the transected uterine horn. On recovery, ewes were checked daily for oestrous behaviour using a vasectomized ram, and at oestrus were mated three times with either a fertile $(n=20)$ or a vasectomized ram $(n=8)$.
Ewes were killed on day $13(n=3)$ or day $16(n=25)$. Within an hour of death, each uterine horn was flushed with $10 \mathrm{ml}$ Modified Eagles Medium (MEM) (Gibco Ltd, Paisley) and the flushing fluid collected and stored at $-20^{\circ} \mathrm{C}$ until analysis for the presence of antiviral activity. Great care was taken to ensure that there was no leakage from the intact, pregnant horn to the cut, non-pregnant horn and that there was no contamination during the flushing procedure. Uterine endometrium was collected from both horns and assayed for binding of oxytocin. The masses and gross morphology of corpora lutea were recorded.

Eight of the ewes had jugular venous cannulae inserted after mating to allow the collection of daily blood samples to monitor steroid hormone concentrations in plasma.

Experiment 2. Eight ewes were mated and on day 16 of pregnancy were anaesthetized, as above, for the collection of uterine lymph from lymphatic vessels draining the uterus. Lymphatic pathways were highlighted and lymph collected according to the method of Staples et al. (1982). Briefly, $100-200 \mu$ l Evans Blue $\left(0.5 \%(\mathrm{w} / \mathrm{v})\right.$ in saline, $\left.9 \mathrm{~g} \mathrm{NaCl} \mathrm{l}^{-1}\right)$ were injected beneath the serosal layer of the uterine wall. After approximately $10 \mathrm{~min}$, it was possible to visualize the lymphatic efferents draining the uterus. A single duct was selected for cannulation on the basis of size and accessibility and the obliquely cut end of a cannula was inserted into the vessel towards the uterus. The cannula was secured by suture and lymph collected continuously by allowing it to drip into heparinized tubes that were changed at intervals of $20 \mathrm{~min}$. Lymph samples were centrifuged at $3000 \mathrm{~g}$ for $10 \mathrm{~min}$ to remove cells and then frozen at $-20^{\circ} \mathrm{C}$ until analysed for antiviral activity. Lymph flow rates $\left(\mathrm{ml} \mathrm{h}^{-1}\right)$ were determined gravimetrically. Pregnancy status was confirmed and the masses of corpora lutea recorded after death at the end of the experiment.

Experiment 3. Eight Finn-Dorset ewes were surgically prepared as in Expt 1. After death on day 16 after mating, five ewes were found to be unilaterally pregnant and two nonpregnant ewes had recently re-ovulated on the side of the transected horns. Cross-sectional cylinders of about $1-2 \mathrm{~cm}$ in length of both uterine horns of all ewes were immediately frozen in isopentane cooled in liquid nitrogen, and stored at $-80^{\circ} \mathrm{C}$ for subsequent steroid receptor immunocytochemical studies and autoradiographic and in situ hybridization analysis for localization of oxytocin receptors.

\section{Radioimmunoassays}

Blood samples were centrifuged at $3000 \mathrm{~g}$ for $10 \mathrm{~min}$ and plasma stored at $-20^{\circ} \mathrm{C}$ until analysed.

Progesterone. Plasma concentrations of progesterone were measured by the radioimmunoassay of Hunter et al. (1986). Inter- and intra-assay coefficients of variation were $11.4 \%$ and $6.9 \%$, respectively. Extraction efficiency was $79.3 \%$, and the limit of sensitivity for the assay was $0.42 \mathrm{nmol} \mathrm{l}^{-1}$.

Oestradiol. Oestradiol concentrations were measured in plasma using a modified radioimmunoassay based on reagents Downloaded from Bioscientifica.com at 04/26/2023 06:03:40AM 
Table 1. Summary of results showing concentration of endometrial oxytocin receptors ( $\mathrm{fmol} \mathrm{mg}^{-1}$ protein) and antiviral activity ( $\left(\mathrm{U} \mathrm{ml}^{-1}\right.$ ) of uterine flushes on day 13 and day 16 after mating in transected and intact sheep

\begin{tabular}{|c|c|c|c|c|c|c|}
\hline & \multicolumn{2}{|c|}{$\begin{array}{l}\text { Pregnant } \\
\text { transected }\end{array}$} & \multicolumn{2}{|c|}{$\begin{array}{c}\text { Non-pregnant } \\
\text { transected }\end{array}$} & \multirow[t]{2}{*}{$\begin{array}{l}\text { Pregnant } \\
\text { control }\end{array}$} & \multirow[t]{2}{*}{$\begin{array}{c}\text { Non-pregnant } \\
\text { control }\end{array}$} \\
\hline & $\begin{array}{c}\text { Intact } \\
\text { pregnant }\end{array}$ & $\begin{array}{c}\text { Cut } \\
\text { non-pregnant }\end{array}$ & $\begin{array}{c}\text { Intact } \\
\text { non-pregnant }\end{array}$ & $\begin{array}{c}\text { Cut } \\
\text { non-pregnant }\end{array}$ & & \\
\hline \multicolumn{7}{|c|}{ Oxytocin receptors } \\
\hline Day 13 & $\begin{array}{l}30 \pm 11^{a} \\
(n=3)\end{array}$ & $\begin{array}{c}312 \pm 154^{b} \\
(n=3)\end{array}$ & - & - & - & $\begin{array}{c}24 \pm I 1 \\
(n=3)\end{array}$ \\
\hline Day 16 & $\begin{array}{l}45 \pm 11^{a} \\
(n=17)\end{array}$ & $\begin{array}{c}585 \pm 131^{\circ} \\
(n=17)\end{array}$ & $\begin{array}{c}788 \pm 131^{d} \\
(n=9)\end{array}$ & $\begin{array}{c}960 \pm 148^{\mathrm{d}} \\
(n=9)\end{array}$ & $\begin{array}{c}24 \pm 13^{\mathrm{a}} \\
(n=5)\end{array}$ & $\begin{array}{c}1029 \pm 108^{d} \\
(n=8)\end{array}$ \\
\hline \multicolumn{7}{|c|}{ Antiviral activity } \\
\hline Day 13 & $\begin{array}{l}8.6 \times 10^{6} \\
(n=1)\end{array}$ & $\begin{array}{c}240 \\
(n=1)\end{array}$ & - & - & - & - \\
\hline Day 16 & $\begin{array}{c}5.8 \times 10^{7} \\
\pm 5.2 \times 10^{7, \mathrm{e}} \\
(n=17)\end{array}$ & $\begin{array}{l}2.9 \times 10^{3} \\
\pm 1.2 \times 10^{3 . \mathrm{f}} \\
(n=17)\end{array}$ & neg. & neg. & $\begin{array}{c}4.9 \times 10^{6} \\
\pm 4.4 \times 10^{6} \\
(n=5)\end{array}$ & neg. \\
\hline
\end{tabular}

Values are expressed as means \pm SEM.

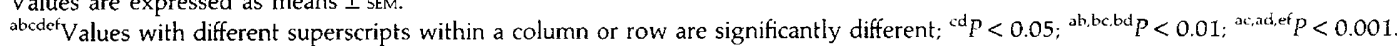
neg: No antiviral activity measured.

(E2 Maia rabbit anti-oestradiol antibody, ${ }^{125}$ I-labelled oestradiol tracer and goat anti-rabbit gammaglobulin coupled to magnetic particles) supplied in an assay kit produced by Serono Diagnostics (E2 MAIA; Serono Diagnostics Ltd, Woking, Surrey) and validated for use in sheep by Beard $e$ t al. (1994). The mean extraction efficiency was $91 \%$. The sensitivity of the assay was $<0.0001 \mathrm{pmol}$ per tube and the inter- and intra-assay coefficients of variation were $6.1 \%$ and $3.4 \%$, respectively.

Oxytocin receptor assay Binding of oxytocin to endometrial membrane preparations was measured using $10 \mathrm{nmol}\left[{ }^{3} \mathrm{H}\right]$ oxytocin $\mathrm{I}^{-1}$ (specific activity $39.3 \mathrm{Ci} \mathrm{mmol}^{-1}$; New England Nuclear, Stevenage, Herts) using the method of Sheldrick and Flint (1985) modified and validated as described by Vallet $e$ al al. (1990). Nonspecific binding was $0.36 \%$ of total label. Inter- and intra-assay coefficients of variation were $27 \%$ and $19.9 \%$, respectively. The mean limit of sensitivity of the assay (calculated as two standard deviations from nonspecific binding) was $23 \pm 4 \mathrm{fmol} \mathrm{mg}{ }^{-1}$ protein. Mean concentrations of oxytocin receptors at oestrus were $1299 \pm 199 \mathrm{fmol} \mathrm{mg}^{-1}$ protein, and for ewes at day 16 of pregnancy, $24 \pm 13 \mathrm{fmol} \mathrm{mg}^{-1}$ protein.

\section{Steroid receptor immunocytochemistry}

Localization of oestradiol and progesterone receptors was performed as described by Wathes and Hamon (1993). Briefly, formaldehyde-fixed $6 \mu \mathrm{m}$ cryostat cross-sections of each uterine horn were treated with monoclonal antibodies against oestradiol receptor ( $\mathrm{H} 222$, the gift of G. L. Greene, University of Chicago, IL) or progesterone receptor (mPR4; Transbio, Paris). Control sections were treated with rat (oestradiol receptors) or mouse (progesterone receptors) IgG. Receptor visualization was achieved using (i) second antibody of rabbit anti-rat or -mouse $\operatorname{IgG}$ (ii) polyclonal peroxidase-antiperoxidase and (iii) 3,4,3',4'-tetra-aminobiphenylhydrochloride.

Four cross-sections from each horn were treated with each primary antibody, and two with control IgG. Samples of uterus from a ewe in oestrus were included as a positive control. The intensity of nuclear staining on each section was assessed by an observer unaware of the sample identity on a scale of 0 (absent), 1 (weak), 2 (moderate) and 3 (intense). The uterine regions scored were: luminal epithelium, superficial glandular epithelium, deep glandular epithelium, caruncular stroma, deep stroma and myometrium. Values from the IgG-treated control sections were always zero.

\section{Autoradiography}

Oxytocin receptors were localized by autoradiography, using the iodinated oxytocin receptor antagonist $\mathrm{d}\left(\mathrm{CH}_{2}\right)_{5}\left[\mathrm{Tyr}(\mathrm{Me})^{2}, \mathrm{Thr}_{4}, \mathrm{Tyr}-\mathrm{NH}_{2}{ }^{9}\right]$-vasotocin (supplied by $\mathrm{M}$. Manning, Medical College of $\mathrm{Ohio}, \mathrm{OH}$ ) as described by Ayad et al. (1991a) and Wathes and Hamon (1993). Sections were treated either with the antagonist alone (total binding) or with the further addition of $10 \mu \mathrm{mol}$ unlabelled oxytocin $\mathrm{l}^{-1}$ (Bachem UK Ltd, Saffron Walden, Essex) (nonspecific binding). Between 4-6 pairs of each type of section were processed from each uterine horn of the same ewes that were used for the immunocytochemistry study. The sections were exposed to Hyperfilm (Amersham International plc, Amersham, Bucks) for 3 days. Optical density measurements were made from each of the six uterine regions described above for each section using a Seescan Image Analysis System (Seescan Imaging plc, Cambridge) as described by Wathes and Hamon (1993). 

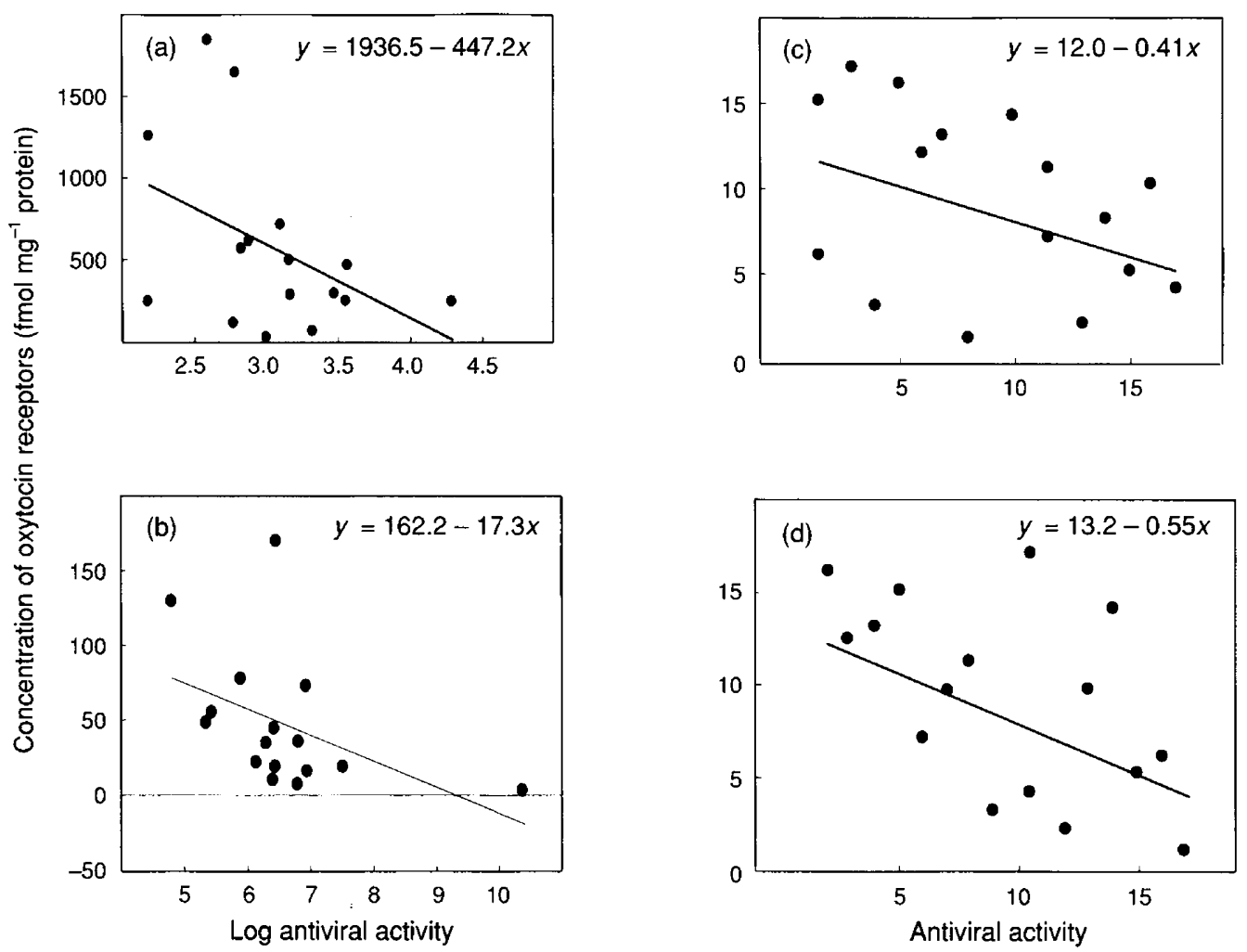

Fig. 1. Regression lines showing the relationship between oxytocin receptor concentration ( $\mathrm{fmol} \mathrm{mg}^{-1}$ protein) and the log of the antiviral concentration in (a) the cut, non-pregnant horns and (b) the intact, pregnant horns of ewes with transected uteri, on day 16 of pregnancy. The ranked data using the Spearman correlation coefficients are illustrated in (c) for the non-pregnant horn and (d) for the pregnant horn (see text for statistical analysis). The regression equation for the non-pregnant horn is not significant $(P=0.11$ ), that for the pregnant horn is significant $(P=0.03)$, but the slopes do not differ significantly from each other.

\section{In-situ hybridization}

mRNA encoding oxytocin receptors was localized on frozen $18 \mu \mathrm{m}$ sections of uterine horn as described by Stevenson $e$ al. (1994). Sections were fixed in $4 \%(w / v)$ paraformaldehyde, dehydrated in ethanol, dried, then hybridized overnight with a 45 mer oligonucleotide probe to the ovine oxytocin receptor, end-labelled at the $3^{\prime}$ end with ${ }^{35}$ S-labelled dATP (NEN Research Bioproducts, Du Pont de Nemours, Dreiech). Control slides were hybridized with the corresponding sense sequence. Slides were exposed to film for 14 days. Absorbance measurements of the different uterine regions were made as described above.

\section{Antiviral assay}

Interferons (IFN) in uterine flushings were measured by cytopathic effect inhibition (antiviral) assay (Meager, 1987; Abayasekara et al., 1995). Briefly, cultures of Madin-Darby bovine kidney (MDBK) cells were exposed to dilutions of IFN standards or unknowns before addition of Semliki Forest virus (SFV); the inhibitory effect of IFN on the cytopathic action of SFV was determined by measuring cell density. When assaying sheep uterine flushings it was necessary to dilute unknown samples between $10^{3}$ - and $10^{7}$-fold to obtain $\mathrm{ED}_{50}$ values. Each concentration of unknown sample was assayed in duplicate wells. All additions were made in culture medium containing $10 \%(\mathrm{v} / \mathrm{v})$ fetal calf serum, $50 \mathrm{iu}$ penicillin $\mathrm{ml}^{-1}, 50 \mu \mathrm{g}$ streptomycin $\mathrm{ml}^{-1}$ and $2 \mathrm{mmol}$ L-glutamine $\mathrm{l}^{-1}$ in Minimal Essential Medium with Earle's salts (Gibco Ltd, Paisley); cultures were at $37^{\circ} \mathrm{C}$ in $5 \% \mathrm{CO}_{2}$ in air. The lowest concentration of SFV required to cause $100 \%$ cell death was initially determined by serial dilutions and culture under assay conditions, and this concentration was used throughout.

Concentrations of brIFN (laboratory standard) were standardized against the 1st International Standard (1987), containing human recombinant $\alpha_{I I}$ IFN, obtained from the National Institute of Biological Standards and Control (Potters Bar, Herts). Potency of the laboratory standards was $1.57 \mathrm{iu} \mathrm{ng}^{-1}$. Wells containing only cells (no virus controls) and cells plus virus (no IFN controls) were run on each plate, and the mid-point between these values was used to calculate concentrations of IFN causing $50 \%$ inhibition of cytopathic effect. These end points were then expressed in terms of the International Standard.

\section{Statistical analyses}

Results are expressed as means \pm SEM. The statistical significance of difference observed between the two uterine horns of similarly treated sheep were analysed using paired $t$ tests. 

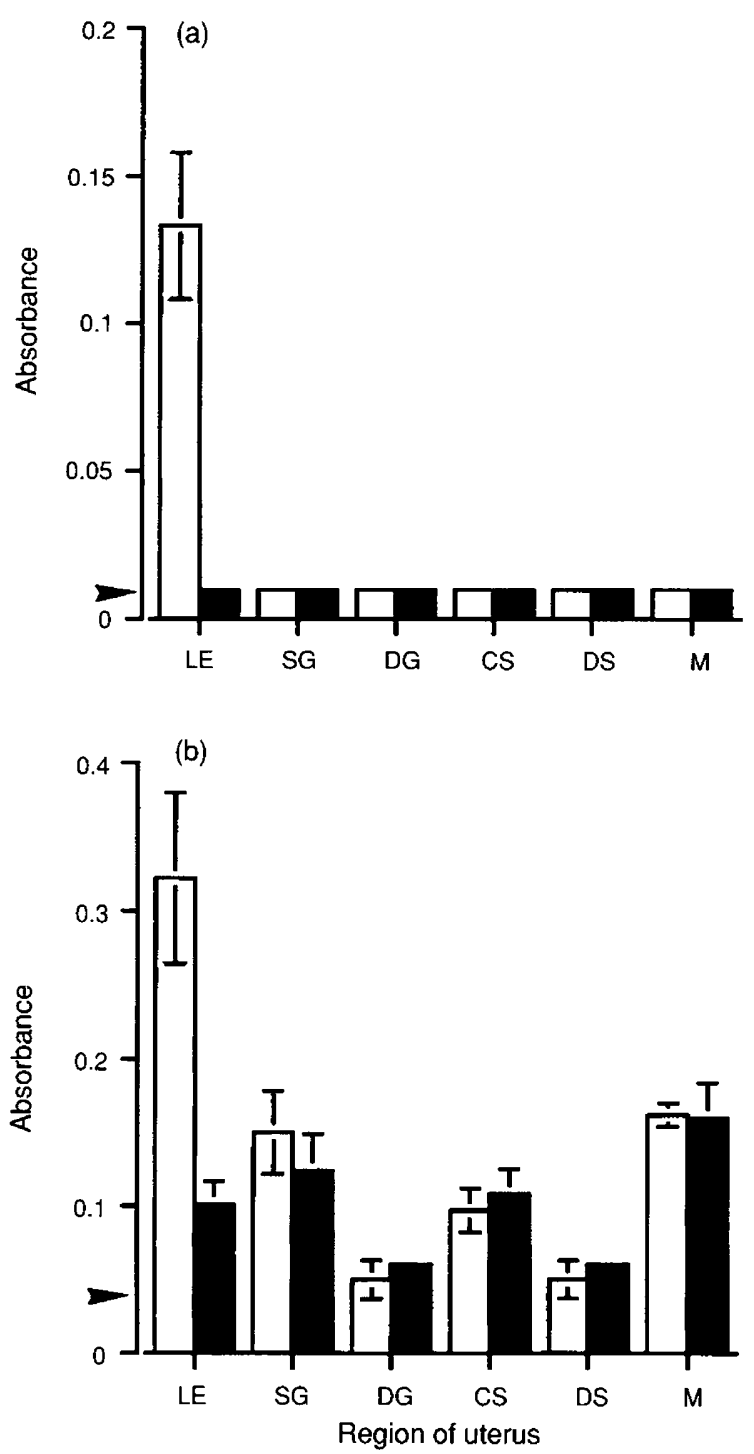

Fig. 2. Absorbance measurements (arbitrary units) from autoradiographs of (a) mRNA encoding oxytocin receptors, and (b) ${ }^{125}$ I-labelled binding sites for oxytocin, in different uterine regions of ( $\square$ ) the cut, nompregnant horn and ( $)$ the intact pregnant horn from ewes with transected uteri on day 16 of pregnancy $(n=5$, mean \pm SEM). The regions assessed were: LE: luminal epithelium; SG: superficial glands; DG: deep glands; CS: caruncular stroma; DS: deep stroma and $\mathrm{M}$ : myometrium. All absorbance values for mRNA for oxytocin receptors, except in the luminal epithelium of the non-pregnant horn, were below the detection limit (shown by arrowheads). The concentration of endometrial oxytocin receptors ( $\mathrm{fmol} \mathrm{mg}^{-1}$ protein) was $314.0 \pm 62.1$ for the cut, non-pregnant horn, and $23.3 \pm 7.6$ for the intact pregnant horn $(n=3)$.

Comparisons between groups of sheep were made using unpaired $t$ tests. Data on oxytocin receptors were analysed untransformed, but antiviral activity data were log-transformed before analyses, to provide homogeneity of variance across the groups of sheep and to normalize the distribution of the data.

Linear regression analysis was performed to assess whether there were linear relationships between corpora lutea and oxytocin receptor data and antiviral activity, and correlation coefficients calculated. To assess further the relationship between antiviral activity and concentrations of oxytocin receptors in both horns of sheep with transected uteri and, because of the inherently large variation in antiviral activity of pregnant horns (two sheep had in excess of $10^{8}$ units $\mathrm{ml}^{-1}$ ) Spearmans (non-parametric) correlation coefficient was calculated using ranked data. The immunocytochemical data of steroid hormone receptors were analysed using repeated measures of ANOVA or the Wilcoxon signed ranks test using the BMDP suite of statistical programmes.

\section{Results}

The results indicate the presence of high antiviral activity with low oxytocin receptor concentration in the intact pregnant horn, and low antiviral activity with high oxytocin receptor concentration in the non-pregnant horn of transected ewes from Expt 1 examined on days 13 and 16 after mating (Table 1). Overall, there was a highly significant negative correlation between concentrations of oxytocin receptors, and antiviral activity $(r=-0.59 ; P<0.001)$. However, there were no significant correlations between uterine flush antiviral activity and endometrial concentrations of oxytocin receptors in either the cut, non-pregnant horns alone, or the intact pregnant horns alone, of individual transected ewes $(r=-0.250 ; P>0.1$ and $r=-0.269 ; P>0.1$, respectively; Fig $1 \mathrm{a}, \mathrm{b}$ ). However, using the Spearman correlation coefficients with ranked data, for the pregnant horn, a significant negative correlation of $r=-0.554$ $(P<0.05)$ was obtained, compared with a non-pregnant horn negative correlation of $r=-0.414$ which was not significant $(P=0.111$ ) (Fig. Ic, d). There was no statistical evidence for differences in either antiviral activity or concentration of oxytocin receptors in ewes where there was a corpus luteum present on the ovary ipsilateral to the cut, non-pregnant horn compared with those where corpora lutea were present only ipsilateral to the intact, pregnant horn. There was no significant correlation between antiviral activity measured in the cut non-pregnant and intact pregnant horns of individual sheep with transected uteri on day 16 of pregnancy $(P>0.1)$. In non-pregnant sheep with transected uteri, 16 days after mating, there was a significant positive correlation between the oxytocin receptor concentration in two horns $(r=0.818, P<0.001)$ but there was not a significant difference between the mean concentrations.

The mean jugular plasma concentration of progesterone on day 16 of pregnancy in transected ewes was $7.9 \pm 0.6 \mathrm{nmol} \mathrm{l}^{-1}$ $(n=5)$ and mean oestradiol concentration was $2.9 \pm 0.4 \mathrm{pmol}^{-1}$ $(n=5)$.

There was no measurable antiviral activity in uterine lymphatic drainage taken from ewes at day 16 of pregnancy in Expt 2.

\section{Autoradiography and in-situ hybridization}

The results of Expt 3 showed that the increase in oxytocin receptor concentration noted in the non-pregnant horn in the receptor-binding studies in Expt $I$ could be attributed solely to an increase in receptors in the luminal epithelium (Fig. 2). This pattern of localization is the same as that seen on days 14-15 of the oestrous cycle at the onset of luteolysis (Ayad $e t$ al., 
(a)

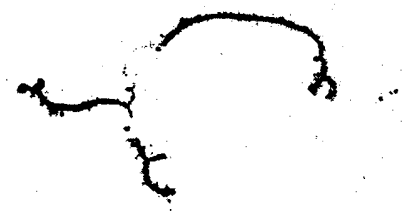

(b)

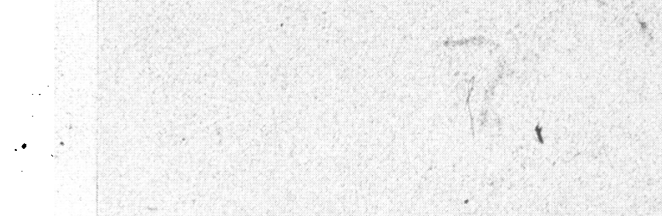

Fig. 3. In-situ hybridization showing oxytocin receptor mRNA expression in (a) the cut, non-pregnant horn, and (b) the intact, pregnant horn of a ewe with a transected uterus on day 16 of pregnancy. Receptor localization is confined to the luminal epithelium of the non-pregnant horn. Scale bar represents $2 \mathrm{~mm}$.

1991b; Wathes and Hamon, 1993; Stevenson et al., 1994). The localization of oxytocin receptors in the luminal epithelium of a non-pregnant transected horn is clearly shown (Fig. 3).

\section{Immunocytochemistry}

From the repeated measures analysis, there was a clear significant difference $(P=0.04)$ in the intensity of staining for oestradiol receptors between the pregnant and non-pregnant horns (Fig. 4, Table 2) and overall, there were highly significant differences between areas $(P<0.001)$. In the pregnant horn, no oestradiol receptors were detectable in the luminal epithelium or superficial glands, and moderate concentrations were present in the caruncular stroma, deep stroma, and myometrium. In contrast, receptors were present in both the luminal and superficial glandular epithelium of the non-pregnant horn, Staining in the luminal epithelium was somewhat uneven, in that it was not present in all cells (see Fig. 5 for representative sections). Receptor concentrations in the two regions of stroma and in the deep glands were greater than those in the pregnant horn, although those in the myometrium were similar. Thus, there was a significant difference in the stage of pregnancyarea interaction for oestradiol receptors $(P=0.022)$. This pattern in the non-pregnant transected horn of ewes at day 16 of pregnancy is similar to that occurring at oestrus in nonpregnant sheep. Steroid receptor values are compared with previous results from cyclic and pregnant sheep (Table 2).

Progesterone receptors were not detectable in the luminal or glandular epithelium of either uterine horn, but were visualized in stroma and myometrium (see Figs $4 \mathrm{~b}$ and 5 and Table 2). As a result, the progesterone receptor analyses were confined to the three non-epithelial areas of the uterus using the Wilcoxon signed ranks test. Overall, there was no difference between horns owing to pregnancy status (pregnant $=0.65$, nonpregnant $=0.94$, not significant). However, there was a significant pregnancy-area interaction in that there were more receptors in the caruncular stroma in the non-pregnant horn (Fig. 4). The values for progesterone receptors in the endometrium of pregnant and non-pregnant horns were similar to those of ewes at oestrus and at day 14 of the cycle, although progesterone receptor concentrations in the myometrium were higher at oestrus (Table 2).

\section{Discussion}

The results of the present study show that the presence of a conceptus is associated with high antiviral activity and low concentrations of endometrial oxytocin receptors. However, in the same systemic steroid hormone environment, endometrial concentrations of oxytocin receptors are high in the uterus where there is no conceptus. This implies that there is a local suppressive effect of the conceptus on endometrial oxytocin receptor concentrations. This is in agreement with Vallet and Lamming (1991) who found that ovine conceptus secretory proteins and bovine recombinant interferon- $\alpha_{I}$ decreased endometrial oxytocin receptor concentrations when infused into the uterus of progesterone-treated ovariectomized and cyclic ewes, and confirms that the inhibitory action of progesterone on endometrial oxytocin receptors disappears by day 13 of pregnancy in the absence of the local influence of the conceptus. The antiluteolytic protein produced by the developing conceptus in sheep from day 13 to day 21 of pregnancy (Godkin et al., 1982) is IFN- $\tau$ (Imakawa et al., 1987; Stewart et al., 1987; Roberts et al., 1992). The presence of IFN- $\tau$ is reflected by antiviral activity in the uterine flushes (Pontzer et al., 1988; Roberts et al., 1989). Studies have shown that IFN- $\tau$ has a localized effect on the uterine luminal epithelium (Knickerbocker and Niswender, 1989; Lamming et al., 1991; for review see Stewart et al., 1992). In the present study, the isolated non-pregnant horn of the pregnant, transected ewes also had antiviral activity, albeit, several orders of magnitude less than that in the pregnant horn. The reason for this is unclear, but it is definitely associated with the pregnancy in the intact horn, and not with surgical intervention, since uterine flushings from non-pregnant transected ewes had no anti-viral activity.

We had not expected to measure antiviral activity in the uterine flush from transected, non-pregnant horns in pregnant sheep.oThe low concentrations present/precluded further 
characterization of the antiviral activity so it is not known if the antiviral activity is due to IFN- $\tau$. If the activity is IFN- $\tau$, it must be assumed that the IFN in the nonpregnant horn results either from uptake from the systemic circulation or from transfer locally from the adjacent pregnant uterine horn. This would necessitate release of IFN- $\tau$ into either the bloodstream or the lymphatic drainage. Antiviral activity has not been measured systemically in pregnant ewes, and although it has been detected in the uterine venous drainage (Schalue-Francis et al., 1991), concentrations were very low. We were not able to measure antiviral activity in the uterine lymphatics. Uptake from the systemic circulation would require active sequestration of the antiviral activity into the uterine lumen. Studies in vitro have shown that very low concentrations of bovine recombinant interferon stimulate progesterone production from luteinized granulosa cells and cultured luteal cells (Luck et al., 1992). If IFN escapes from the uterine lumen, there could be a systemic role for low concentrations of IFN- $\tau$ which would facilitate the continued secretion of luteal progesterone, thereby assisting in the maintenance of pregnancy. However, Godkin et al. (1984) found that IFN- $\tau$ had no effect on dispersed luteal cells, while Wiltbank et al. (1992) suggested that IFN- $\tau$ does not have a luteal protective role since purified

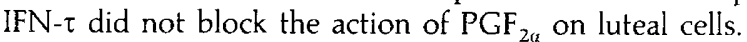

Endometrial concentrations of oxytocin receptors were low on day 16 in the pregnant horn of the transected ewe, as expected at this time in pregnancy (Sheldrick and Flint, 1985; Flint and Sheldrick, 1986). However, in the cut non-pregnant horn, although the concentrations of endometrial oxytocin receptors were significantly higher than in the intact, pregnant horn of the same sheep $(P<0.001)$, the concentrations were lower than in the transected hom of non-pregnant sheep, possibly due to the low concentrations of IFN- $\tau$ therein, $(P<0.05)$. The difference in oxytocin receptor concentrations between the intact and cut horns of the pregnant sheep clearly suggests that the conceptus is acting locally to suppress the development of these endometrial oxytocin receptors on the luminal epithelium.

The in-situ hybridization and oxytocin-binding studies showed that in the cut, non-pregnant horn of pregnant ewes, the increase in oxytocin receptors was confined to the luminal epithelium, whereas in non-pregnant ewes, receptors spread from this site to the superficial and deep glands and caruncular stroma as luteolysis proceeded (Ayad et al., 1991b; Wathes and Hamon, 1993). The development of these additional receptors appears to be regulated differently from those in the luminal epithelium (Wathes and Lamming, 1995), and probably requires an increase in circulating oestradiol (for example, that associated with ovulatory follicles), which did not occur in the pregnant, transected ewes in this study. There is ample evidence that oestradiol can enhance endometrial oxytocin receptor concentrations (McCracken, 1980; Hixon and Flint, 1987; Vallet et al., 1990; Fairclough and Lau, 1992; Zhang et al., 1992; Beard and Lamming, 1994; Beard et al., 1994). Since oxytocin causes $\mathrm{PGF}_{2 u}$ release from the non-pregnant, but not the pregnant horn, in uterine-transected ewes (Payne and Lamming, 1992, 1994), it must be concluded that the luminal epithelial cells are responsible for this response.

Plasma progesterone concentrations were lower in the pregnant, transected ewes $\left(7.9 \pm 0.6 \mathrm{nmol} \mathrm{l^{-1 }}\right)$ than those
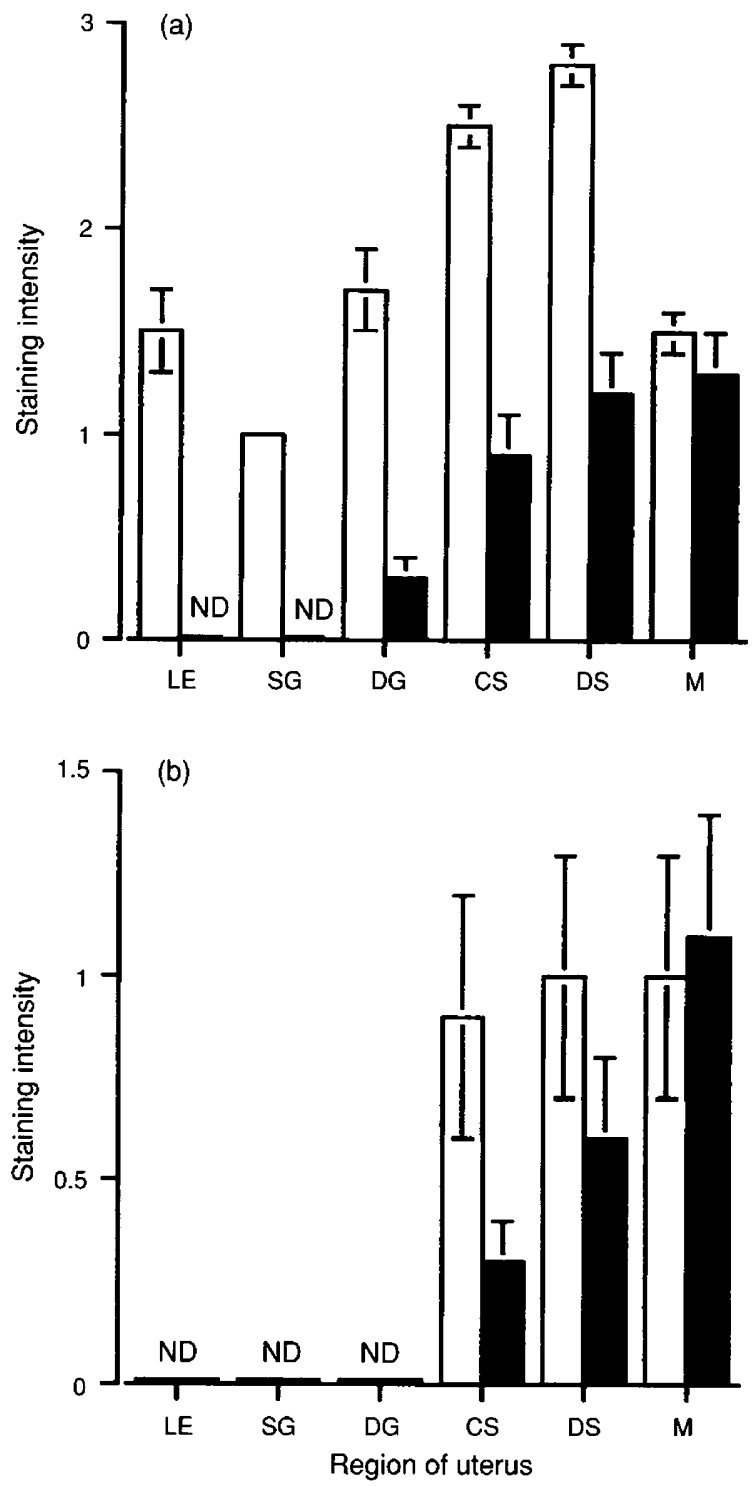

Fig. 4. Comparison of steroid receptor concentrations for (a) oestradiol and (b) progesterone in ( $\square$ ) nonpregnant and $(\square)$ pregnant horns of ewes with transected uteri on day 16 of pregnancy $(n=3$, mean \pm SEM). Measurements of staining intensity were taken on a scale: 3: intense; 2: moderate; 1: faint and 0 : not detectable (ND). Note different vertical axes in (a) and (b). LE: luminal epithelium; SG: superficial glands; DG: deep glands; CS: caruncular stroma; DS: deep stroma and $M$ : myometrium.

during normal pregnancy as found in our previous studies with this breed (11.8 $\pm 1.9 \mathrm{nmol} \mathrm{I}^{-1}$; J. T. Parkinson and G. E. Lamming, unpublished observations). This could reflect the release of $P G$ from the transected, non-pregnant uterine horn (as reported by Payne and Lamming, 1994) but this should have been destroyed by passage through the lungs before reaching the corpus luteum on the ovary ipsilateral to the intact pregnant horn.

The suggestion has been made that progesterone eventually downregulates its own receptor, and this allows oxytocin receptors to develop (McCracken et al., 1981). Vallet et al. (1990) concluded that initiation of luteolysis requires progesDownloaded from Bioscientifica.com at 04/26/2023 06:03:40AM 
Table 2. Comparison of uterine steroid receptor immunocytochemistry of pregnant transected ewes with previous results from cyclic and pregnant ewes

\begin{tabular}{|c|c|c|c|c|c|c|}
\hline & \multicolumn{6}{|c|}{ Region of uterus } \\
\hline & LE & SG & DG & CS & DS & M \\
\hline \multicolumn{7}{|c|}{ Oestradiol receptors } \\
\hline $\begin{array}{l}\text { Oestrus* } \\
(n=6)\end{array}$ & $0.8 \pm 0.4$ & $2.0 \pm 0.3$ & $2.6 \pm 0.3$ & $2.3 \pm 0.2$ & $2.5 \pm 0.2$ & $2.7 \pm 0.2$ \\
\hline $\begin{array}{l}\text { Day I4 NP* } \\
(n=5)\end{array}$ & $0.3 \pm 0.2$ & ND & ND & $0.9 \pm 0.3$ & $0.7 \pm 0.3$ & $0.3 \pm 0.3$ \\
\hline $\begin{array}{l}\text { Day } 21 P^{*} \\
(n=5)\end{array}$ & $\mathrm{ND}$ & ND & $0.5 \pm 0.3$ & $0.9 \pm 0.4$ & $0.5 \pm 0.3$ & $0.9 \pm 0.4$ \\
\hline $\begin{array}{l}\text { Day } 16 \\
\text { Trans P } \\
(n=3)\end{array}$ & ND & ND & $0.3 \pm 0.1$ & $0.9 \pm 0.2$ & $1.2 \pm 0.2$ & $1.3 \pm 0.2$ \\
\hline $\begin{array}{l}\text { Day } 16 \\
\text { Trans NP } \\
(n=3)\end{array}$ & $1.5 \pm 0.2$ & $1.0 \pm 0.0$ & $1.7 \pm 0.2$ & $2.5 \pm 0.1$ & $2.8 \pm 0.1$ & $1.5 \pm 0.1$ \\
\hline \multicolumn{7}{|c|}{ Progesterone receptors } \\
\hline $\begin{array}{l}\text { Oestrus* } \\
(n=6)\end{array}$ & ND & ND & ND & $0.8 \pm 0.2$ & $1.2 \pm 0.3$ & $2.3 \pm 0.3$ \\
\hline $\begin{array}{l}\text { Day } 14 \mathrm{NP}^{*} \\
(n=3)\end{array}$ & $0.3 \pm 0.3^{\dagger}$ & $0.4 \pm 0.3^{+}$ & ND & $0.5 \pm 0.3$ & $0.5 \pm 0.2$ & $1.2 \pm 0.6$ \\
\hline $\begin{array}{l}\text { Day } 21 \mathrm{P}^{*} \\
(n=5)\end{array}$ & ND & $0.5 \pm 0.3$ & ND & ND & ND & $1.5 \pm 0.4$ \\
\hline $\begin{array}{l}\text { Day } 16 \\
\text { Trans P } \\
(n=3)\end{array}$ & ND & ND & ND & $0.3 \pm 0.1$ & $0.6 \pm 0.2$ & $1.1 \pm 0.3$ \\
\hline $\begin{array}{l}\text { Day } 16 \\
\text { Trans NP } \\
(n=3)\end{array}$ & ND & ND & ND & $0.9 \pm 0.3$ & $1.0 \pm 0.3$ & $1.0 \pm 0.3$ \\
\hline
\end{tabular}

Values are means \pm SEM of independent ranking of immunocytochemical staining intensity on a scale of $0-3$ (3= maximum). LE: luminal epithelium; SG: superficial glands; DG: deep glands; CS: caruncular stroma; DS: deep stroma; M: myometrium; NP: control, non-pregnant; P: control, pregnant; Trans P: pregnant horn in ewe with transected uterus; Trans NP: nonpregnant horn in pregnant ewe with transected uterus; ND: not detected.

* Data taken from Wathes and Hamon, 1993.

${ }^{+}$Receptors were detectable only in one animal.

terone and, therefore, progesterone receptors. The effect of IFN- $\tau$ probably also requires progesterone and, therefore, progesterone receptors (Vallet and Bazer, 1989). The data presented here do not, however, provide any evidence for either the downregulation or reappearance of progesterone receptors in the period during which oxytocin receptors develop. Progesterone receptors were present at low concentrations in the stroma and myometrium of pregnant and nonpregnant horns of the ewes with transected uteri and absent from the luminal epithelium, the site of development of oxytocin receptors in the non-pregnant horn. This pattern resembles that seen on day 14 of the oestrous cycle and day 21 of pregnancy (Wathes and Hamon, 1993). This earlier study showed that progesterone receptors in the luminal epithelium are downregulated on about day 8 of the cycle, some 6 days before oxytocin receptor formation, and do not reappear until day 1 of the following cycle, probably as a result of oestrogenic stimulation during oestrus. These results suggest, therefore, that the inhibitory action of progesterone involves a stromal component which inhibits epithelial oxytocin receptors. Eventually, this effect is lost during the cycle, but during pregnancy it is maintained by the local action of IFN- $\tau$. The exact pathway involved remains to be determined (Wathes and Lamming, 1995).

In contrast to the lack of effect of pregnancy on formation of progesterone receptors, there was a major difference in oestradiol receptor concentration between the pregnant and nonpregnant horns of the ewes with transected uteri. The staining pattern in the non-pregnant horn was similar to that previously reported at oestrus, whereas in the pregnant horn, it closely resembled that seen on day 14 of the oestrous cycle and day 21 of pregnancy (Wathes and Hamon, 1993).

Previous studies (for example, Ott et al., 1993; Wathes and Hamon, 1993), which used ovulatory ewes as controls, were unable to differentiate between an inhibitory action of IFN- $\tau$ on concentrations of oestrogen receptors and an increase in receptor concentrations preceding ovulation. In contrast, the present data suggest that the presence of the conceptus has a local inhibitory action on the development of oestradiol and oxytocin receptors. The inhibition of development of oestradiol receptors in pregnancy is supported by the work of Cherny et al. (1991) who showed suppression of oestradiol Downloaded from Bioscientifica.com at 04/26/2023 06:03:40AM 

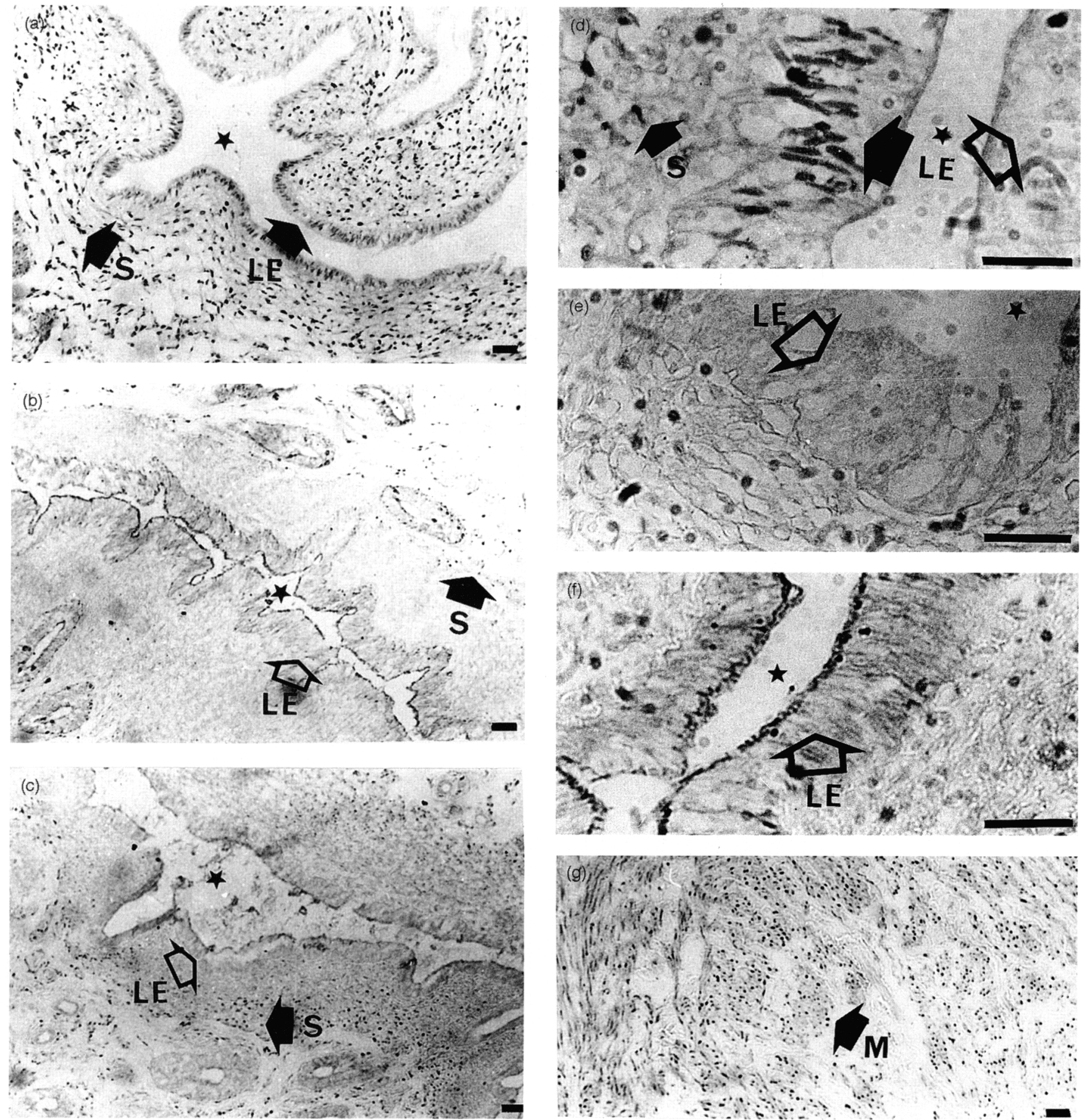

Fig. 5. Sections of uterine horns from ewes with transected uteri collected on day 16 of pregnancy and immunostained with either oestradiol receptor $(a, d, e)$ or progesterone receptor $(b, c, f, g)$ antibody. In all cases solid arrows indicate nuclei with positive staining and open arrows show non-reactive cells. $\star$ Uterine lumen. Scale bars represent $20 \mu \mathrm{m}$. (a) Non-pregnant horn showing intense staining of oestradiol receptors in the luminal epithelium (LE) and caruncular stroma (S). (b) Pregnant and (c) non-pregnant horns of the same ewe treated with progesterone receptor antibody. Note the absence of staining in nuclei of the luminal epithelium, although there are a few positive cells in the stroma. (d) Non-pregnant and (e) pregnant horn from the same ewe showing positive staining for oestradiol receptors in some (but not all) nuclei in the luminal epithelium of the non-pregnant horn, whereas staining was always absent in the pregnant horn. (f) Higher magnification of pregnant horn showing no staining for progesterone receptors in the luminal epithelium. $(\mathrm{g})$ View of the myometrium $(\mathrm{M})$ of the pregnant horn showing that progesterone receptors are present in this tissue, although absent from the epithelium (f). 
receptors in the endometrium in ewes at day 15 of pregnancy and suggested that an embryonic factor might be involved. It remains to be determined whether IFN- $\tau$ acts independently to suppress both oestradiol and oxytocin receptor populations or whether, as suggested by Flint et al. (in press), the inhibitory action on oxytocin receptors is mediated by a reduction in concentrations of oestradiol receptors.

In conclusion, the presence of a conceptus in the pregnant horn of sheep locally suppressed the development of oestradiol and oxytocin receptors, but had no apparent effect on the progesterone receptor concentrations.

The authors thank the staff of the Joint Animal Breeding Unit at Sutton Bonington for their surgical assistance and M. Batten, M-J. Searle and E. Darwash for their invaluable assistance, and G. L. Greene for the generous gift of the oestradiol receptor antibody. They are grateful to the BBSRC for supporting this work, and to P. H. Riley of the Cripps Computing Centre, University of Nottingham, for statistical analysis of the antiviral and hormone receptor data.

\section{References}

Abayasekara DRE, Sheldrick EL, Flick-Smith HC and Flint APF (1995) Role of protein kinase $C$ in the inhibitory action of trophoblast interferons on expression of the oxytocin receptor in sheep endometrium Endocrine 3 $151-158$

Ayad VJ, Guldenar SEF and Wathes DC (1991a) Characterization and localization of oxytocin receptors in the uterus and oviduct of the non-pregnant ewe using an iodinated receptor antagonist Journal of Endocrinology 128 $187-195$

Ayad VJ, Matthews EL, Wathes DC, Parkinson TJ and Wild ML (1991b) Autoradiographical localization of oxytocin receptors in the endometrium during the oestrous cycle of the ewe Journal of Endocrinology 130 199-206

Beard AP and Lamming GE (1994) Oestradiol concentrations and the development of the uterine oxytocin receptor and oxytocin-induced PGF $_{2,4}$ release in ewes Journal of Reproduction and Fertility 100 469-475

Beard AP, Hunter MG and Lamming GE (1994) Quantitative control of oxytocin-induced $\mathrm{PGF}_{2 u}$ release by progesterone and oestradiol in ewes Journal of Reproduction and Fertility 100 143-150

Cherny RA, Salamonsen LA and Findlay JK (1991) Immunocytochemical localization of oestrogen receptors in the endometrium of the ewe Reproduction Fertility and Development 3 321-331

Fairclough RJ and Lau TM (1992) Hormonal control of concentrations of endometrial oxytocin receptors in the ewe Reproduction, Fertility and Development 4 313-320

Flint APF and Sheldrick EL (1983) Evidence for a systemic role for ovarian oxytocin in luteal regression in sheep Journal of Reproduction and Fertility 67 $215-225$

Flint APF and Sheldrick EL (1986) Ovarian oxytocin and the maternal recognition of pregnancy Journal of Reproduction and Fertility 76 831-839

Flint APF, Stewart HJ, Lamming GE and Payne JH (1992) Role of the oxytocin receptor in the choice between cyclicity and gestation in ruminants Journal of Reproduction and Fertility Supplement 45 53-58

Flint APF, Lamming GE, Stewart HJ and Abayasekara DRE (1994) The role of the endometrial oxytocin receptor in determining the length of the sterile oestrous cycle and ensuring maintenance of luteal function in early pregnancy in ruminants Philosophical Transactions of the Royal Society B $\mathbf{3 4 4}$ 291-304

Flint APF, Riley PR, Kaluz S, Stewart HJ and Abayasekara DRE The sheep endometrial oxytocin receptor. In Oxytocin (Ed. R Ivell). Pergamon Press, Oxford (in press)

Godkin JD, Bazer FW, Moffatt J, Sessions F and Roberts RM (1982) Purification and properties of a major, low molecular weight protein released by the trophoblast of sheep blastocysts at day 13-21 Journal of Reproduction and Fertility 65 141-150

Godkin JD, Bazer FW and Roberts RM (1984) Ovine trophoblast protein 1, an early secreted blastocyst protein, binds specifically to uterine endometrium and affects protein synthesis Endocrinology 114 120-130
Hixon JE and Flint APF (1987) Effects of a luteolytic dose of oestradiol benzoate on uterine oxytocin receptor concentrations, phosphoinositide turnover and $\mathrm{PGF}_{21}$ secretion in sheep Journal of Reproduction and Fertility 79 457-467

Hunter MG, Southee JA, McCleod BJ and Haresign W (1986) Progesterone pretreatment has a direct effect on GnRH-induced preovulatory follicles to determine their ability to develop into normal corpora lutea in anoestrous ewes Journal of Reproduction and Fertility 76 349-363

Imakawa K, Anthony RV, Kazemi M, Marotti KR, Polites HG and Roberts RM (1987) Interferon-like sequence of ovine trophoblast protein secreted by embryonic trophectoderm Nature 330 377-379

Inoue T, Kimura T, Azuma C, Inazawa J, Takemura M, Kikuchi T, Kubota Y, Ogita $\mathbf{K}$ and Saji $\mathbf{F}$ (1994) Structural organization of the human oxytocin receptor gene Journal of Biological Chemistry 26932 451-32 456

Knickerbocker JJ and Niswender GD (1989) Characterization of endometrial receptors for ovine trophoblast protein-1 during the estrous cycle and early pregnancy in sheep Biology of Reproduction 40 36I-369

Lamming GE, Flint APF and Vallet JL (1991) Trophoblast interferons act locally to suppress the uterine oxytocin receptor in sheep Journal of Reproduction and Fertility Abstract Series 8 Abstract 38

Luck MR, Shale JA and Payne JH (1992) Direct stimulation of bovine ovarian progesterone secretion by low concentrations of $\alpha$-interferon Journal of Endocrinology 135 R5-R8

McCracken JA (1980) Hormone receptor control of prostaglandin $F_{2 \mu}$ secretion by the ovine uterus Advances in Prostaglandin and Thromboxane Research 8 1329-1344

McCracken JA, Carlson JC, Glew ME, Goding JR, Baird DT, Green K and Samuelson B (1972) Prostaglandin $\mathrm{F}_{2 \alpha}$ identified as a luteolytic hormone in the sheep Nature New Biology 238 129-134

McCracken JA, Schramm W, Barcikowski B and Wilson L (1981) The identification of prostaglandin $\mathrm{F}_{2 a}$ as a uterine luteolytic hormone and the hormonal control of its synthesis Acta Veterinaria Scandinavica Supplementa 71 71-78

Meager A (1987) Quantification of interferons by antiviral assays and their standardization. In Lymphokines and Interferons; a Practical Approach pp 129-147 Eds MJ Clemens, AG Morris and AJH Gearing. IRL Press, Oxford.

Moore RM and Rowson LEA (1966) Local maintenance of the corpus luteum in sheep with embryos transferred to various isolated portions of the uterus Journal of Reproduction and Fertility 12 539-550

Ott TI, Zhou Y, Mirando MA, Stevens C, Harney JP, Ogle TF and Bazer FW (1993) Changes in progesterone and oestrogen receptor mRNA and protein during maternal recognition of pregnancy and luteolysis in ewes Journal of Molecular Endocrinology 10 171-183

Payne JH and Lamming GE (1992) Uterine prostaglandin production from early pregnant and non-pregnant sheep Journal of Reproduction and Fertility Abstract Series 10 Abstract 20

Payne JH and Lamming GE (1994) The direct influence of the embryo on uterine $\mathrm{PGF}_{211}$ and $\mathrm{PGE}_{2}$ production in sheep Journal of Reproduction and Fertility 101 737-741

Pontzer CH, Torres BA, Vallet JL, Bazer FW and Johnson HM (1988) Antiviral activity of the pregnancy recognition hormone ovine trophoblast protein- 1 Biochemical and Biophysical Research Communication 152 801-807

Roberts RM, Imakawa K, Niwando Y, Kazemi M, Malathy PV, Hansen TR, Glass AA and Kronenberg LH (1989) Interferon production by the preimplantation sheep embryo Journal of Interferon Research 9 175-187

Roberts RM, Cross JC and Leaman DW (1992) Interferons as hormones of pregnancy Endocrine Reviews 13 432-452

Rozen F, Russo C, Banville D and Zingg HH (1995) Structure, characterization and expression of the rat oxytocin receptor gene Biochemistry 92 200-204

Schalue-Francis TK, Farin PW, Cross JC, Keisler D and Roberts RM (1991) Effect of injected bovine interferon $\alpha-1$ on oestrous cycle length and pregnancy success in sheep Journal of Reproduction and Ferfility 91 347-356

Sheldrick EL and Flint APF (1985) Endocrine control of uterine oxytocin receptors in the ewe Journal of Endocrinology 196 249-258

Staples LD, Fleet IR and Heap RB (1982) Anatomy of the utero-ovarian lymphatic network and the composition of afferent lymph in relation to the establishment of pregnancy in the sheep and goat Journal of Reproduction and Fertility 64 409-420

Stevenson KR, Riley PR, Stewart HJ, Flint APF and Wathes DC (1994) Localization of oxytocin receptor mRNA in the ovine uterus during the oestrous cycle and early pregnancy Journal of Molecular Endocrinology 12 93-105 
Stewart HJ, McCann SHE, Barker PJ, Lee KE, Lanming GE and Flint APF (1987) Interferon sequence homology and receptor binding activity of ovine trophoblast antiluteolytic protein Journal of Endocrinology 115 R13-R15.

Stewart HJ, Guesdon FMJ, Payne JH, Charleston B, Vallet IL and Flint APF (1992) Trophoblast interferons in early pregnancy of domestic ruminants Journal of Reproduction and Ferility Supplement 45 59-68

Vallet JL and Bazer FW (1989) Effect of ovine trophoblast protein-1, oestrogen and progesterone on oxytocin-induced phosphatidylinositol turnover in endometrium of sheep Journal of Reproduction and Fertility 87 755-761

Vallet JL and Lamming GE (1991) Ovine conceptus secretory proteins and bovine recombinant interferon $\alpha$-I decrease endometrial oxytocin receptor concentrations in cyclic and progesterone-treated ovariectomized ewes Journal of Endocrinology 131 475-482

Vallet JL, Lamming GE and Batten M (1990) Control of endometrial oxytocin receptor and uterine response to oxytocin by progesterone and oestradiol in the ewe Journal of Reproduction and Ferility 90 625-634
Wathes DC and Hamon M (1993) Localization of oestradiol, progesterone and oxytocin receptors in the uterus during the oestrous cycle and early pregnancy of the ewe Journal of Endocrinology 138 479-491

Wathes DC and Lamming GE (1995) The oxytocin receptor, luteolysis and the maintenance of pregnancy Journal of Reproduction and Fertility Supplement $\mathbf{4 9}$ 53-67

Wathes DC, Gilbert CL and Ayad VJ (1993) Interactions between oxytocin, the ovaries and reproductive tract in the regulation of fertility in the ewe. In The Neurohypophysis: A Window on Brain Function Eds WG North, AM Moses and L. Share. Annals of the New York Academy of Sciences 689 396-410

Wiltbank MC, Wiepz GJ, Knickerbocker JJ, Belfiore CJ and Niswender GD (1992) Proteins secreted from the early ovine conceptus block the action of prostaglandin $\mathrm{F}_{211}$ on large luteal cells Biology of Reproduction 46 475-482

Zhang J, Weston PG and Hixon JE (1992) Role of progesterone and oestradiol with regulation of uterine oxytocin receptors in ewes Journal of Reproduction and Fertility 94 395-404 